\title{
大阪キタに打ける路上活動者とその社会的ネットワーク
}

—梅田新歩道橋界隈を中心として—

\section{三木 和 美}

I はじめに
(1) 研究の目的
(2) 研究の対象
(3) 研究の方法
II 路上活動者の基本的属性とその活動
内容
(1) 個々の路上活動者の属性
(2) 類型別の活動内容と考察
III 路上活動者の時間的・空間的棲み分
け

(1) 曜日別の活動変化

(2) 一日における時間分布

（3）一日における空間分布

IV 路上活動者を取り巻く社会的環境

(1) 警察

(2) イベントやメディア機関

(3) ファンや客

$\mathrm{V}$ 路上活動者とインターネット

VI むすびにかえて一時間的・空間的な 活動と社会的ネットワークの観点から一

キーワード：路上活動者, キタ, 社会的ネットワーク, 時間地理学, 社会と空間

\section{I はじめに}

(1) 研究の目的 近年ストリート・カルチャ 一への注目が集まりはじめ, そこで「都市的な るもの」との関係が問われている。こうしたス トリート研究に積極的に取り組んできたカルチ ユラル・スタディーズ研究者らは, 従来の都市 研究は，日常生活における現象を軽視しがちで あったと指摘する。地理学において加藤は, そ の複雑な構造ゆえに「もはや『都市』なるもの を『一望』することは通常不可能となり，われ われの都市とのかかわり方はきわめて局所的な
ものにならざるをえない」と，自明視されてき た地理学的な知を問い直す中で,「歩く者」の 視点から都市現象を見る必要性を説いた。

本稿では，現代都市において主体的に空間を 選択し，何らかの形態で人々を楽しませる活動 をする者を対象としている。「ストリート・パ フォーマー」,「ストリート・アーティスト」, 「ストリート・ミュージシャン」などの路上活 動者について, わが国では建築学や民族芸術学 の分野から以下のような研究がなされてきてい る。小平ら, 大影らは, 京都におけるストリー ト・ミュージシャンが, 人との接触が得られや

1）関根康正「ケガレから都市の歩道へ」UP 10，2004，14-19頁。

2）上野俊哉·毛利嘉孝『カルチュラル・スタディーズ入門』筑摩書房，2001，254頁。

3）加藤政洋『大阪スラムと盛り場一近代都市と場所の系譜学』創元社，2002，5頁。

4) 加藤政洋「ポストモダン人文地理学とモダニズム的『都市へのまなざし』一ハーヴェイとソジャの批判的検討を通して 一」人文地理 $51,1999,164-182$ 頁。

5）小平弥史・大影佳史・川崎清「ストリート・ミュージシャンの演奏空間に関する研究その 1 一都市における演奏空間の 配置に関する基礎的考察一」日本建築学会大会学術講演梗概集 F-1，1995，185-186頁。大影佳史·小平弥史・川崎清 「ストリート・ミュージシャンの演奏空間の配置に関する研究その 2 一京都に㧍ける演奏空間の配置に関する調查・研究 一」日本建築学会大会学術講演梗概集 F-1, 1995, 187-188頁。 
すいかどうかを基準に演奏空間を選んでいるこ とを解明した。阪田らは，大阪市の繁華街にお けるストリート・パフォーマンスに焦点を当て, パフォーマンス活動の特性によって選択される 空間に違いが見られることを明らかにした。水 谷は, 韓国ソウルのストリート・ミュージシャ ンが募金活動を通して観客と問題意識を分かち 合おうとするところに韓国の独自性を見出した。 パフォーマンスの活動意義が無償の自己表現だ けではないことへ言及していること，そして空 間特性について詳細に調査されていることは興 味深いが，しかしながらパフォーマーの目的や 活動分布に影響する要因や空間の特徵との有機 的な結びつきへの考察には及んでいない。

早くからストリート・ミュージシャンの存在 に注目していたサウンドスケープの分野では, ミュージシャンを街の観察者という観点から捉 える。南田は, 大阪の主要ターミナル駅周辺を 対象にした研究から，「『ストリート・ミュージ シャンが生きやすい空間』というのも，実際に はなかなかにもろいもの」であると考察してい る。

海外の地理学的研究では, ショッピングモー ルの彩りとして雇用されるパフォーマーについ
10)

ての記述や，発展途上国で生活必需品を売る久 トリート・ベンダーの活動についての記述にと どまる。国内では山口が大阪・ミナミのストリ ート・パフォーマー，ストリート・アーティス トを取り扱っている。この研究は, 現代の都市 内部の盛り場をミクロな立場から捉えた地理学 的研究が十分ではない状況において, 都市地理 学に新たな視点を付け加え, 提示しょうとする ことに成果があった。しかしながら都市空間に おける新しい活動主体としてパフォーマーを分 析する枠組み，あるいはパフォーマーと彼らを 取り巻く人々との関係やメディアがパフォーマ 一の活動に及ぼす影響などを検討する余地を残 したままであった。

上記の諸研究の示唆や課題から, 本稿では, 路上で活動する者の実態をミクロ的に捉えると ともに，その背後にある彼らとストリート空間， あるいは社会環境とがどのように結びつき相互 に影響を及ぼすかについて議論を試みる。そし て「みずからの身体を起点として社会と空間と の関わりを媒介する」彼らから現代都市空間の 構造をほぐす糸口を見出し, 従来の地理学研究 で弱いとされる，人々と社会的環境を関連させ て考察する視点を補うことを目的とする。具体

6）阪田らは, パフォーマンス内容をその表現手段から「音楽型」,「創作型」,「曲芸型」「「ダンス型」に四類型化した。さ らにパフォーマンス空間を三次元的な物的環境に着目して「閉鎖的で単調な構成の通路空間」,「開放的な溜まり空間」, 「複雑な構成の通路空間」,「開放的で単調な構成の溜まり空間」に四類型化した。阪田弘一・柏原士郎・吉村英祐・横田 隆司「繁華街におけるストリート・パフォーマンスの実態とその発生場所の空間特性」日本建築学会計画系論文集 541 , 2001，123-130頁。

7）水谷清佳「韓国ソウル・大学路のストリート・ミュージックからみるマダンの文化」民族芸術21，2005，185-192頁。

8）中川真「『ストリート・ミュージックのサウンドスケープ』へ」サウンドスケープ 4，2002，39-40頁。

9）南田勝也「ストリート・ミュージックの都市空間：大阪都市部のフィールドワークを元に」サウンドスケープ 4, 2002, 54-62頁。

10) Goss, J., "The "magic of the mall": an analysis of form, function, and meaning in the contemporary retail built environment', Annals of the Association of American Geographers, 83-1, 1993, pp. 18-47.

11) Hays-Mitchell, M., 'Streetvending in Peruvian cities: the spatio-temporal behavior of Ambulantes', The Professional Geographer, 46-4, 1994, pp. 425-438.

12）山口晋「大阪・ミナミに扔りストリート・パフォーマーとストリート・アーティスト」人文地理54，2002，173-189頁。

13）後に山口は, ミナミのストリート・パフォーマーを対象に, 彼らを取り巻く規制の実態について明らかにしている。山 口晋「規制をめぐるInteraction一ストリート・ミュージック，排除か容認か？一（特集：ストリート・ミュージシャ ン)」サウンドスケープ 4，2002，41-49頁。

14）前揭 3 ） 213 頁。

15) Hägerstrand, T., 'On the definition of migration, in Jones, E', Readings in Social Geography, Oxford University Press, 1975, pp. 200-209. 原著は1969年の Scandinavian Population Studies, 1, pp. 63-72. 所収。時間地理学は, 社会的 行為の環境を行為の単なる「容れ物」と見なしがちな社会学の傾向の見直しにつながるとして評価されてきた。このノ 
的には，時間地理学の立場から，時間的・空間 的パターンに注目して路上活動者の実態を活動 の束 (バンドル) として把握する。さらに，社 会学的な観点から, 対面型コミュニケーション のネットワークおよびウェブ・サイトを通じて 構築される社会的ネットワークについて触れる。 また，ここで取り上げるネットワークは，相互 利益のための調整と協力を容易にする社会的な つながりの特徴を表す「ソーシャル・キャピタ ル」の一形態としても考えられる。

(2) 研究の対象 本稿では三大都市圈のうち 大阪を取り上げ，二大繁華街としてミナミと並 ぶキタ（大阪市の北区と中央区の一部）を研究対 象に選定した（第 1 図）。キタでは数年前に梅田 地下街における路上活動が全面禁止になったた め, 梅田新歩道橋の界隈が路上活動のメッカに なっている。また，「諸々の社会的コミュニケ ーションの中継点となり, 社会の記憶装置とも なっている都市の本質は劇場や街路, 市場によ く現れる」という点から, この歩道橋界隈では, 路上活動者をめぐるコミュニケーションやネッ トワークが作り上げられている可能性が十分に 考えられる。選定地域は,「都市らしさ」を象 徵する若者の路上活動とその社会関係の検証に 適していると思われる。

(3) 研究の方法 路上活動者の活動実態を把 握するため, 本稿では現場での観察と聞き取り

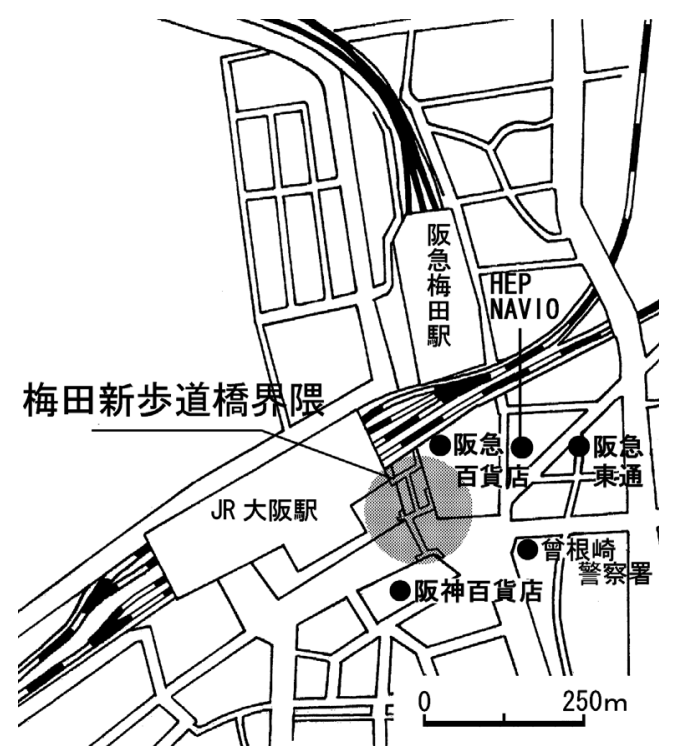

第 1 図調査対象地域

Figure 1. The study area of Kita, Osaka.

調査を主な手段とし，各種ウェブ・サイトを利 用した。2004年 6 月から 7 月にかけてのべ13日 間，正午過ぎからの路上活動者の様子を， 発生 場所，活動内容などに注目して記録した。そし て観察と共に, 梅田新歩道橋界噮で活動する 86 団体（1 人ないし複数の構成員から成る。これらの ものに番号 $\mathrm{P} 1 \sim \mathrm{P} 86$ を割り当て, 以下の本文・図表 中でこれを用いる）と警察官 2 人に対して聞き取 り調査を行った。調査研究プロセスにおいて, その場所で生きる人々の実感を反映させるため に，インフォーマントの語りに重きを置いて,

点についてギデンズもその有益性を認めている。Giddens, A., 'Comments on the theory of structuration', Journal for the Theory of Social Behaviour, 13, 1983, pp. 75-80.

16）大谷によれば, 社会的ネットワークとは，「居住地域や職業活動を基盤とする集団のような構造概念では包括されない 社会関係の秩序を説明」する分析概念であり，藤崎が指摘するように「都市的環境のもとで形成される社会関係を記述す るのに有効である」。大谷信介『現代都市住民のパーソナル・ネットワーク一北米都市理論の日本的解読一』ミネルヴァ 書房，1995，18頁。藤崎宏子『高齢者・家族・社会的ネットワーク』培風館，1998，11頁。

17）ロバート・D・パットナム（坂本治也・山内富美訳）「ひとりでボウリングをするーアメリカにおけるソーシャル・キ ヤピタルの減退一」(宮川公男・大守隆編『ソーシャル・キャピタル一現代経済社会のガバナンスの基礎一』東洋経済新 報社, 2004) 58 頁 [Putnam, R. D., 'Bowling alone: America's declining social capital', Journal of Democracy, 6-1, 1995, pp. 65-78.]

18） 1963年に（株）松下電器が建設し, 大阪市に寄贈した歩道橋。JR大阪駅をはじめ, 阪神百貨店, 阪急百貨店, 大丸百 貨店といったデパートや，阪急東通商店街，北新地，扔初天神などの繁華街を結び，幹線道路をまたぐ形で立地している。

19）吉見俊哉「都市的なるものと祝祭性」(藤田弘夫・吉原直樹編『都市とモダニティ』ミネルヴァ書房，1995）145頁。

20）調查期間は，2004年 6 月13日（日），18日（金），20日（日），24日（木），26日（土），28日（月）， 7 月 2 日（金）， 3 日 (土)，4 日 (日)，5日（月），19日（月），23日（金）２5日（日）ののベ13日間。ただし，この間，7月11日の参議 院選挙に向けて, この歩道橋界郎でも選挙活動が行われていた。 
会話の一部を本文中にも適宜引用した。

\section{II 路上活動者の基本的属性とその活動内容}

（1）個々の路上活動者の属性 活動内容につ いて, 商行為の有無や取り扱う商品・サービス の内容をもとに，ストリート・ミュージシャン， 美術系アーティスト, ベンダー, その他（プレ イヤー）の四つに分類した上で，梅田新歩道橋 界隈で活動する者の基本的属性について第 1 表 にまとめた。性別について見ると男性の活躍が 目立ち, 男女ともに構成人数は 1 人の場合が多 い。活動者の年齢から，キタでは20代の若者が 中心となってパフォーマンスをしている様子が うかがえる。また,「ターミナル盛り場」であ るキタらしく，電車を移動手段とする者の割合 が高い。そのため多くの活動者は手荷物をコン パクトにまとめている。他方，大きな荷物が多 い, バンド形式のミュージシャンは自動車で移 動していた。活動頻度を見ると，週に 1，2 回 程度定期的に活動する者が多い。活動内容から， キタにおいては，ミナミのようなダンス・パフ オーマンスは観察されず，ミュージシャンと美 術系アーティストが主な活動者と言える。彼ら がホームページの URL を記載したビラを客に 配る様子がよく観察されたことから，ホームぺ ージの有無について調べてみると大半の活動者 が運営していることがわかった。

(2) 類型別の活動内容と考察 次に, 彼らの 活動の様子を具体的に見ていきたい。ちなみに, 同一団体が日によって異なるタイプの活動を行 うということはなかった。

a 、ミュージシャン 彼らは宣伝のための路 上活動という色が強い。「テレビ大阪でやって
第1 表 路上活動者の属性

Table 1. Attributes of street performers.

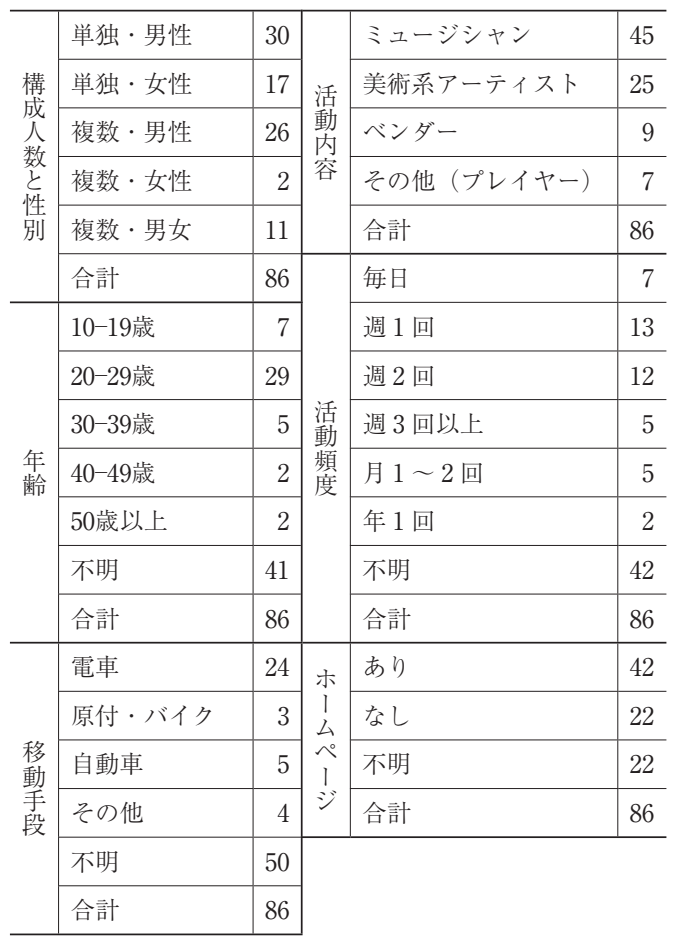

単位: 組

（聞き取り調查などをもとに作成）

いる○○のオープニングを歌っています。セカ ンド・アルバム売り出し中です」,「次回のライ ブのチケットを持ってきました。興味のある人 はぜひ…」(P16)，などと盛んに曲の間にアナ ウンスを行う。実際，路上活動を始めて日が浅 いミュージシャンのなかには，「路上，恥ずか しいけどやらなあかん。宣伝のために」(P4)， 「今日はライブの宣伝で来たようなものだけど, これからちょくちょく路上にも来ようかと」 （P6）といった意見も聞かれた。

b . 美術系アーティスト 布を敷いてポスト カードサイズのイラストや写真，詩を書きつけ

21） キ夕の中心には JR・私鉄・地下鉄の「始発・終着・連絡駅」である大阪駅・梅田駅があり, 郊外から多くの通勤・通 学者や買い物客等を集める。サントリー不易流行研究所編『変わる盛り場一「私」がつくり遊ぶ街一』学芸出版社, 1999 , 30 頁。

22）梅田の路上活動者の多くは，投げ銭が生活の主な糧ではない点でプロの大道芸人や街商とは様相が異なる。「ミュージ シャン」はプロ志向の高い若者が多いと言え,「ベンダー」は, 食品や玩具等を主な商品とする街商に対して, 装飾品を 提供する。 
た物等を並べて販売する者が中心である。

彼らは自己表現やコミュニケーションの場と して歩道橋空間を捉えている傾向にある。P62 は，路上に出たきっかけは「自らの個展の宣伝 のため」だったが，様々な人との出会いが楽し くて何年も「ストリート」を続けているという。 P66 は「人と関わりたくて」という理由が第一 で，「自分の表現を吐き出す場」を求めて路上 活動を始め, P57 は「しゃべってんのが楽し い!」という理由から活動を続けている。

c. ベンダー 路上活動者自身が作ったネッ クレスやピアスといった装飾品類を販売する夕 イプと，海外などから買い付けてきた出来合い 品を販売するタイプとが混在する。前者の多く は，歩道橋上で商品を展示しつつ，客が立ち止 まらない間はせわしなく次の作品あるいは商品 を作っている。

彼らは収入を得るために路上販売をしている ようである。P72 は,「大学出て, 会社にも勤 めたけど，これでしか生きていけない」と，連 日「お金がないから」歩道橋にやってくる。自 らの活動を「商売」と称し,「詩とかイラスト やってる人らって, 自分の内面を出してる感 じ」だとして一線を引く。P73 は夫の失業をき っかけにアクセサリーの製作を始め, P75 も 「ダンナの稼ぎだけじゃ食っていけない」こと を活動理由として語る。

d. その他 ミュージシャンでもなく, 物品 を陳列・販売しているでもない多様なパフォー マンスが該当し，ここでは「プレイヤー」とも 称す。

足下に集金箱のような物が見られることもあ ることから，彼らもまた収入を期待していると 思われるが，ベンダーのように代金は定まって いないため，チップ制に似たやりとりがされて いた。

以上, 活動者をその内容から四つのタイプに 分けて, 活動の様子と目的を簡単に触れた。彼
らが梅田新歩道橋界隈で活動するねらいには,

(1)収入につながる販売, (2)他所における活動 (ライブ, 展覧会等) や知名度を上げるための PR，そして，(3)歩道橋に集う客やファンある いは他の活動者とコミュニケーションを行うと いう三つの意図が考えられる。ミュージシャン の活動目的は, (2)が高く, 相対的に(3)や(1)が低 い傾向にあり, 美術系アーティストのねらいは (2)が低く，(1)よりも(3)が高い。ベンダーとプレ イヤーに関しては, 扱うものが物品かサービス かの相違はあるものの, (2), (3)よりも(1)に重点 が置かれている点で同じ傾向にある。

このように活動の内容や意義が異なる彼らが, 歩道橋界隈の路上空間をどのように共有してい るのかを次章で見ていきたい。

\section{III 路上活動者の時間的・空間的棲み分け}

梅田新歩道橋界隈においてどのような路上活 動者がいつ, どこへ出現するのか, その活動分 布を把握するために，まず曜日別に路上活動者 数の変化を読み取り, 続いて一日に扔ける時間 的・空間的な分布を個別に捉えていく。

(1) 曜日別の活動変化 第 2 図は, のべ13日 間の調查期間に扮いて, 日曜, 土曜, 金曜, 平 日（月，木）の路上活動者数の平均を表したも のであるが, 平日に比べて, 週末や休日に数が 多いことがわかる。休日を前にした土曜・金曜 (週末) は19時以降に路上活動者数が増える傾 向にある一方で, 平日を前にした日曜日は16時 から20時頃までにピークを迎え，それ以降は減 少している。

(2)一日における時間分布 次に, 多様な路 上活動者が観察される週末 ・休日のうち, 調査 期間から任意の金曜日と日曜日に焦点を当てて， 一日における時間的な活動変化をみてみたい。 まず第 3 図および第 4 図から, 美術系アーテ イストとプレイヤー, ベンダーの大半は, 昼夜 間（とりわけ16〜20時）の時間帯に活動している 


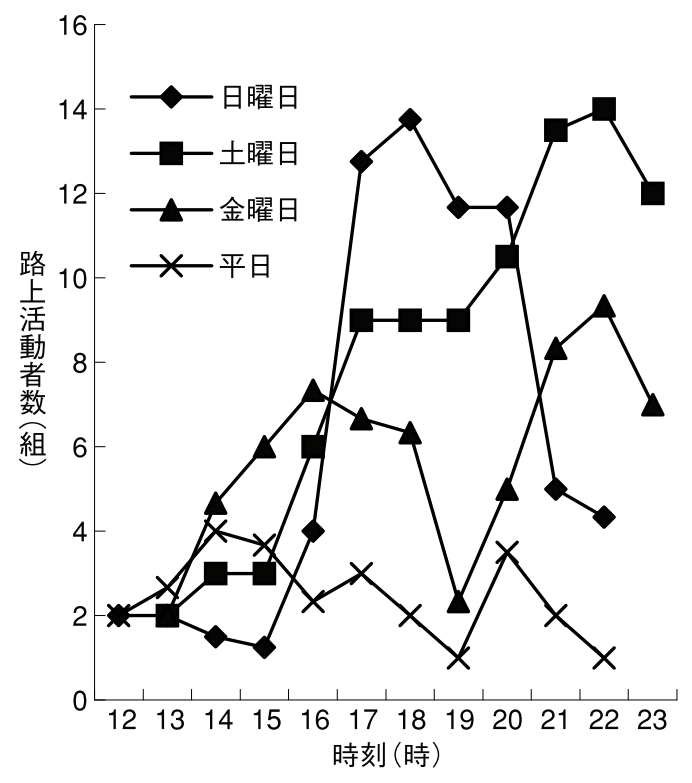

第 2 図 曜日別の路上活動者数の変化（2004年）

Figure 2. Activities of street performers by time and day of the week in Umeda, 2004.

(聞き取り調查などをもとに作成)
のが読み取れる。一日の路上滞在時間を見ると， 美術系アーティスト, プレイヤー, ベンダーで は 7 時間近く居座る者がいるなど，概して長時 間である。他方，ミュージシャンは夜間（20時 以降）に活動数が増加している。路上滞在時間 は長くて 3 時間程度と比較的短い。さらにミュ ージシャンに関して言うと, 第 3 図において P39 と P32, P23 と P38 とはこの日の活動場所 が近接していたため，一方が演奏している間に 他方は休憩しているといった活動時間の譲り合 いがなされている。

このように歩道橋界隈において, ミュージシ ヤンは夜間に, 非ミュージシャンは昼夜間に活 動するという時間的棲み分けに加えて，同業者 の間でも時間的棲み分けが観察された。

（3）一日における空間分布 では，金曜と日 曜において，非ミュージシャンが多い昼夜間と ミュージシャンが多い夜間には空間分布にどの

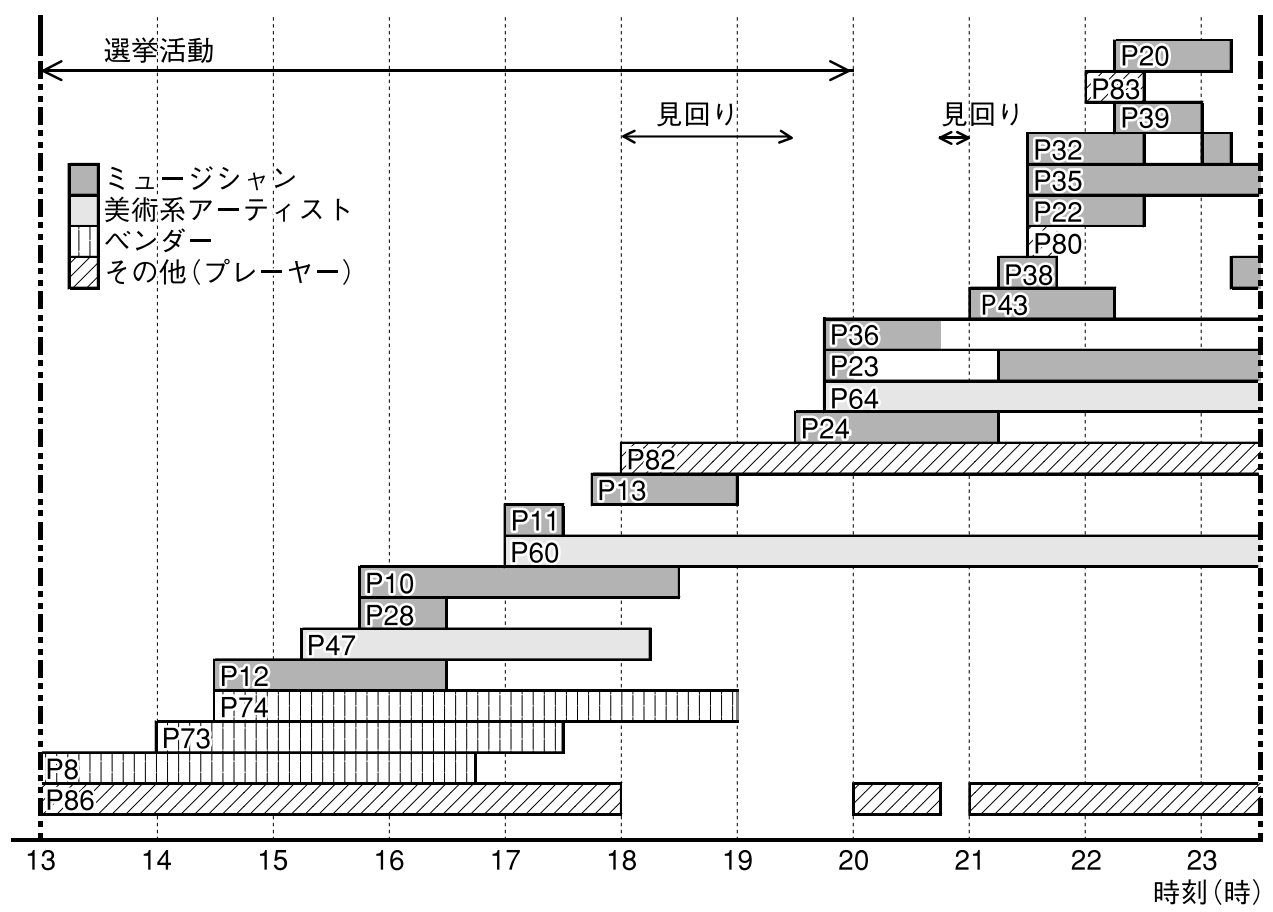

第 3 図 7 月 2 日（金）における路上活動者の時間分布（2004年）

Figure 3. Temporal distribution of street performers on July 2, 2004. 


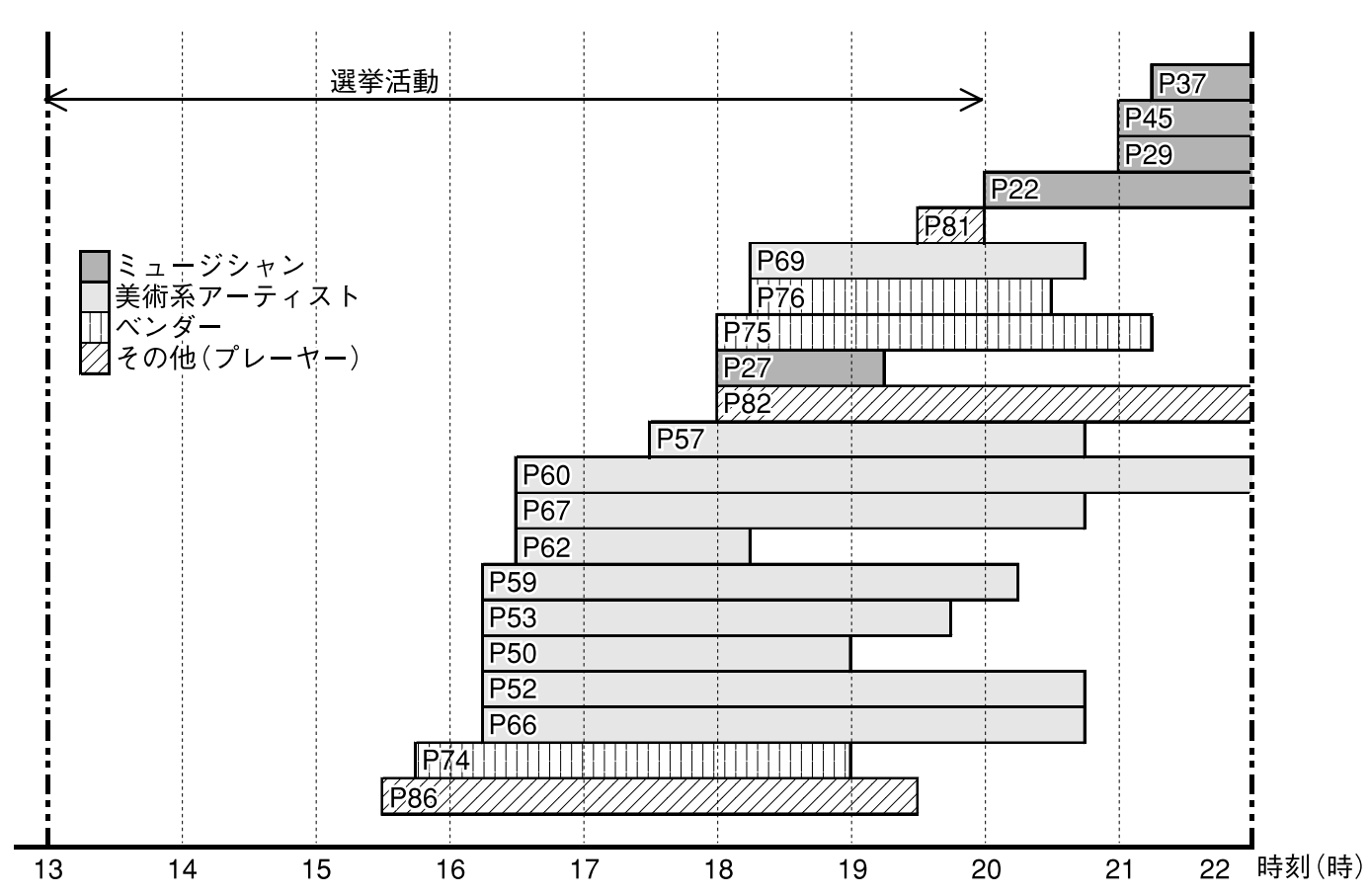

第 4 図 7 月 4 日（日）における路上活動者の時間分布（2004年）

Figure 4. Temporal distribution of street performers on July 4, 2004.

(聞き取り調查などをもとに作成)

ような差異が見られるのであろうか。第 5 図は 7 月 2 日（金）16時と 22 時頃における路上活動 者の活動場所を示したものである。同様に第 6 図は 7 月 4 日（日）17時と22時頃の様子である。 これらによると, 阪神百貨店寄りの通路に美術 系アーティスト, ベンダーが密集しており，阪 神百貨店寄り通路よりも北側にミュージシャン が相互に距離を保つように散在している。

このミュージシャンと非ミュージシャンとの 「空間的棲み分け」は，心理的な側面にも関係 している。すなわち，美術系アーティスト P50 は,「バンドをやっている人には音量を下げる よう頼んだこともある」と言い，「バンドが警 官を呼んでくるようなもの」だから「バンドは こっち(阪神百貨店側) に来てほしくない」と 話していた。このようにバンドに対する多少の 嫌悪感を抱いている非ミュージシャンが少なく ない。「今日いる人（阪神百貨店側に集まる路上活 動者）は，だいたい顔を知っている。バンド系
は単体っていう感じで, バンド系の人とはあま り接触がない」(P50),「選挙前でバンドには (警察の) 規制が厳しいが，僕らにはあんまりな い」(P86) との語りから, ミュージシャン（と りわけバンド系) と非ミュージシャンとは一線 を画していることがうかがえる。

さらにミュージシャンについて，第 5 図と第 6 図を比べてみると, ミュージシャンの活動場 所として定まっているスポットを日時によって 使い回すという同業者間の時間的棲み分けを見 ることができる。例えば，第 5 図において P11 と P23 は同日に時間を変えて, さらに第 5 図 における P35，P43，P36 と，第 6 図における P37，P45，P29 (順は前記に対応）とは同じ時間 帯に日を変えてほほ同じ箇所で活動している。

以上, 制約を受けながら, 歩道橋界隈で展開 される空間と時間の活動パターンを読み取るこ とができた。路上活動者は自由気ままに振る舞 っているわけではなく, 一定の時刻, 一定の場 


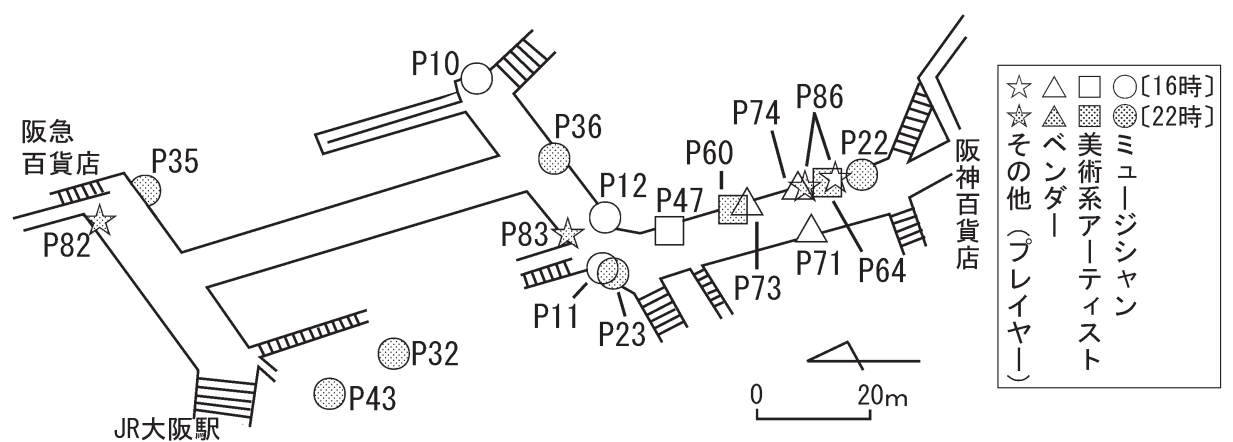

第 5 図 7 月 2 日 (金) における空間分布 (2004年)

Figure 5. Spatial distribution of street performers at 2 time-points on July 2, 2004.

(聞き取り調査などをもとに作成)

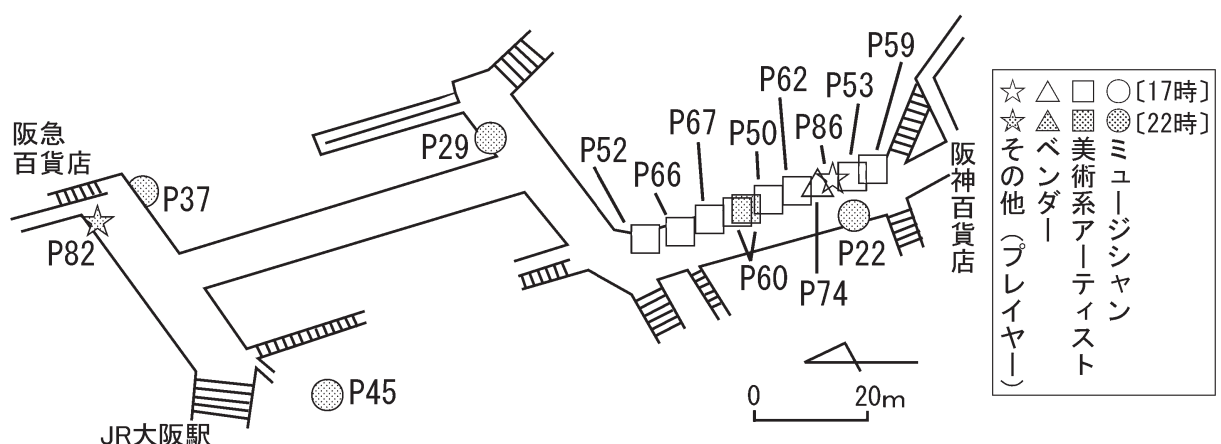

第 6 図 7 月 4 日（日）における空間分布（2004年）

Figure 6. Spatial distribution of street performers at 2 time-points on July 4, 2004.

（聞き取り調査などをもとに作成）

所で，他の一定の人々や資源と共存し，一定の 長さの時間の中で社会的な活動をしていると言 える。

\section{IV 路上活動者を取り巻く社会的環境}

本章ではより社会的な文脈で彼らを位置づけ るために, 警察, 公のイベントやメディア機関, ファンや客を取り上げて以下に述べる。

(1)警察 梅田新歩道橋の近くに㲘根崎警察 署があり，警察官によれば「(歩道橋は) 警察署 から丸見え」の状態にある。路上活動者が道路 交通法に違反している限り, 常に彼らは取締対
象となる。具体的に警察官は歩道橋を巡視し 路上活動者に撤去命令を下したり，時には彼ら を警察署まで連行し，二度としないという誓約 書に署名させたり，罰金を科したりする。

警察官への聞き取り調査により，規制する理 由としては「何でも法律。歩道橋は道路だから。 道幅をせばめるような行為は禁止」であり， 「立ち止まってしゃべったり，座り込んだりす るくらいは注意しない」こと,ただし「ナビ オの所や阪神百貨店の下など，歩道橋以外でな ら許可が下りるところもある」ことなどがわか った。

23）ヘーゲルシュトラント（荒井良雄訳）「地球科学に扔ける人間」(荒井良雄・川口太郎・岡本耕平・神谷浩夫編訳『生活 の空間 都市の時間』古今書院, 1989） 9 頁 [Hägerstrand, T., 'What about people in regional science?', Papers and Proceedings of Regional Science Association, 24, 1970, pp. 7-21.]

24）阪急系の商業施設である HEP NAVIO のこと。第 1 図参照。 
しかしながら，警察の存在は路上活動者にと って権力による制約としてネガティブに影響す るだけではない。警察の見回りによる強制退去 で，それまで路上活動者が占めていた場所が空 き，暫くするとそこへ新しい路上活動者がやっ てくる。定期的に歩道橋空間が誰もいない状態 になるので，路上活動者は早くから来て場所取 りをする必要がない。ミュージシャンに関して はやかましいバンドが強制退去させられること によって，自らの演奏の音が掻き消されてしま う事態を回避できるというメリットもある。見 回りの前後では歩道橋上の活動分布に変化が生 じ，警察官は活動の場所に対して時間的・空間 的なリセットをする役割，いわば「リセッ夕 一」としての機能を担っている。また警察によ って歩道橋界隈の治安が保たれていることは, 路上活動を続けていく上で重要である。

（2）イベントやメディア機関 路上活動者を 受容する側としては，地方自治体等が催す各種 イベント ト ト , 路上活動者を応援するウェブ・サ イトやテレビ番組などを制作するメディア機関 の存在が考えられる。概観すると, 全国規模の ものとローカル規模のものとがある。本稿では 後者について, とりわけ梅田の路上活動者が関 わったことのある大阪府内を中心としたイベン トやウェブ・サイトについて言及する。梅田の 路上という場所と, 梅田以外の場所とで行われ る活動がどのように関連しているのかを事例を 通じて見ていきたい。

a .イベント 梅田の路上活動者が関わった ことのある，大阪府内中心のイベントに注目し， 彼らとファンや客の反応を以下の事例を通して 見てみたい。

\section{【事例 1 ：美術系アーティスト P54】}

2004年 9 月末日にミナミの都市型ホームセン
ターでイベントが催されるとの話があり, 後日 イベントの連絡係から参加日確定の電話が入る。 それ以降, 新作を作りながらもイベントのため の準備を進めていく。知名度を上げる好機とし て参加するが, 初日は作品があまり売れず, 帰 りに心斎橋で路上活動をした。

【事例 2 : ミュージシャン P26】

2004年 7 月に参戦したオーディション（関西 の企業と大手芸能事務所が主催) の結果は残念な ものであったが, ファン以外の多数の人に楽曲

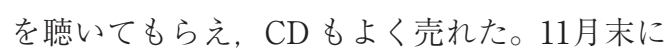
再挑戦したが落選し, 敗者復活戦での投票を歩 道橋上でファンに呼びかけた。

【事例 3 ：ミュージシャン P15】

2001年 7 月には大阪府北部で開催された, 音 楽フェスティバル（ラジオ局と大手楽器メーカー が主催）に参加し，「オーディエンス賞」に選 ばれ，ファンの応援にホームページ内で感謝し ている。また 9 月に出場予定のイベント（大阪 府の公益法人主催) について, その前日ホームペ ージ内においてファンに応援を求めている。後 に，テレビ・ドラマへの出演などを経て，2004 年には某事務所との契約が決まった。

この三事例を通して, その開催趣旨から，ま ちの活性化を図るとともに路上で活動する若者 に活躍の舞台を提供しょうとする, 地方公共団 体や, 地域の企業の好意的な意図が推し量られ る。ミュージシャンや美術系アーティストは精 力的に効率良くイベントをこなしている。イベ ントへの参加を通じて, その勝敗結果に関わら ず，新規ファンの拡大を狙うと同時に，既存の ファンとの結びつきを固めょうとしているよう に見える。

b. メディア機関 2001年前後からストリー ト・パフォーマーやアマチュア・ミュージシャ

25）ここでいうイベントとは, 合法的に舞台が準備されている点で路上と異なり, 不特定多数に向けて活動する点でストリ 一トと同じ性質を持つ。個人的なライブ活動, 各地で日常的に行なわれているフリーマーケットは除外した。 
ンを応援する趣旨のテレビ番組やウェブ・サイ トが増えてきた。そうしたメディア機関と梅田 の路上活動者との間において, 以下のような関 わりを観察することが出来た。

【事例 1 ：テレビ朝日系「ストリートファイタ ーズ」】

全国のストリート・カルチャーとストリー ト・アーティストを紹介し，応援する2001年に 始まった日本初のテレビ番組である。ストリー トで活動している人であれば誰でも登録するこ とが可能である。梅田のミュージシャン 7 組が この番組に参加し, 毎回路上ライブの曲の間で 人気投票への協力を呼びかけていた。また同サ イトにおいては, 各ミュージシャンの活動場 所・時間・ホームページなどを検索できるよう になっている。

【事例 2 ：ウェブ・サイト「ストリート・パフ オーマー情報板」】

情報サービス提供業者が運営している総合エ ンターテインメント情報サイト内に設けられて いる電子掲示板である。大阪の路上活動者を紹 介するコーナーで，梅田の10組が取り上げられ ている。掲示板では, 一般の人がミュージシャ ンを推薦したり, 詳しい活動情報を求めたり, ミュージシャンが署名活動を呼びかけることも あった。

こうしたテレビ番組やウェブ・サイトは, 無 料で利用できるものが多い。活動者は確立され たシステムに便乗することで，自身が一から
PRする手間を省くことができる上に，キタの 歩道橋空間を超えた広大な宣伝効果を期待でき る。

（３）ファンや客 違法行為でもある路上活動 が, 各地で継続されている背景には, 彼らを熱 心に応援するファンや, 商品を買う客の存在が 欠かせない。本稿ではあまり触れることができ なかったファンや客について, ミュージシャン との関係を次の二事例から考察したい。彼らは， 評判を広めるという目的から, 他の路上活動者 に比べて, よりファンや客との関係を重視して いると考えられる。

【事例 1】仕事を終えて路上ライブ開始前に着 いた女性（20代）は, ミュージシャンに, 誕生 日プレゼントには何がいいか訊いていた。ミュ ージシャンについて「初めての客には愛想がい いけど，私みたいにいつも来ている人には冷た い」と話す。〔2004年 6 月18日19時30分頃の聞 き取り調査」

【事例 2】博多からやってきた20代の女性は, 自身もかつて路上でギターを弾いていた経歴を もつ。ミュージシャンと曲の間に「ぜひ博多に も来てくださいね」と話を弾ませていた。彼女 は「大阪だとこの辺がいいって聞いて」梅田へ 立ち寄ったという。〔2004年 6 月 18 日 21 時過ぎ の聞き取り調査]

このようにファンや客と路上活動者との距離 は非常に近く, 友人感覚で付き合っている。路 上活動者はファンや客の声援に支えられ，また

26）事例 1 の他に,「ゲキバン」(テレビ大阪, 2004年 4 月〜 9 月),「大阪発元気ダッシュ! DOYAH」(NHK 大阪, 2001 年～2005年 2 月),「カウントダウン TV オーディション」(TBS, 2001年〜) などがある。

27）事例 2 の他に,「Artist-Debut. net」（ステレオ・メーカー企画, 2002年〜),「Sounds on Street」(全国 FM 放送協議 会企画，2002年～)，「サイバーシティ ストリートアーティスト」(地域情報提供企業企画，2004年～2006年 7 月時点閉 鎖）などがある。

28）全国の 917 組のミュージシャンが登録されている (2006年 5 月 12 日現在)。一般の人は, 応援するミュージシャンに，パ ソコンあるいは携帯電話 1 台につき 1 票のみ, 路上ライブ当日に投票ができる。上位にランクされたミュージシャンは, 全国放送されるライブの出場権が得られる。

29） 2004年 9 月より閉鎖中。ただし URL は http://www2. takara354. com / cgi-bin / streetbbs / bbs. pl。

30） 2004年 7 月 5 日付で, 大阪市長に提出する「路上演奏許可を求める陳情書」の原本を揭載し, 協力者を求めていた。 
ファンや客も路上活動者を応援することが生き 甲斐になっている模様である。

以上，路上活動者を取り巻く環境について事 例を挙げて述べた。警察や住民の苦情といった 規制は，違法行為をしている路上活動者にとっ ては避けられないものである。他方，行政や各 種メディア機関，ファンや客によって路上活動 は受容されているとも見える。しかしながらイ ベントに参加し，ウェブ・サイト等に登録する には，第一に路上活動者は実際に活動を続けて いる必要がある。イベントに関してはその準備 のために普段の生活時間の一部を割かなければ ならない。また，ファンや客がつき始めると， 気まぐれの時間や場所で活動するわけにはいか なくなる。その一方で，主体的な路上活動は， 地域活性化を図る地方自治体や携帯電話による 視聴者参加型など新しい様式を提案するメディ ア機関に影響を与えてもいる。それはまた活動 者を受け入れる空間の再生産につながる。数年 前まで多数の路上活動者が見られた梅田地下街 と同様に，いつ歩道橋界隈での活動が全面禁止 になるともわからない。このような危うい環境 に梅田の路上活動者は置かれている。

\section{$\mathrm{V}$ 路上活動者とインターネット}

路上活動を一定の場所・時間で継続するのが 難しい公共空間において，梅田の路上活動者は インターネットを活用していることが分かって きた。本章では彼ら自身が運営しているホーム ページに着目し，その機能が路上活動に与える 影響について言及したい。以下，アクセスに至 る経緯に触れた上で，その内容や機能について 具体的に記述していく。

梅田の路上活動者の多くは，立ち寄った人に
ビラやチラシを配る。興味を持った人は, その 紙面に掲載されているホームページの URLを 見てインターネット環境の整った所でアクセス する。アクセスしたホームページ内でさらに他 の路上活動者のリンク先を見つけることもある。 あるいは前章で触れたように, 路上活動者を支 援するサイト上のリンクをたどって各ホームペ ージへ行き着いたりもできる。

次に各ホームページの内容や機能についてい くつか事例を挙げて説明したい。

【事例 1 : ミュージシャン P41 のホームペー :】

「ストリートライブ」のページでは, 「梅田地下 街全面禁止に伴い，一時中止していたストリー トですが，5月14日から再開致します！毎週 金曜日 10 時頃〜梅田歩道橋の端（阪神百貨店 側）の下。注：大雨の場合もしくは諸事情に よりお休みすることもあります。その際は携 帯版プチ寄合所にて告知。と案内が出ている。 〔2004年 8 月 5 日検索〕

【事例 2 : ミュージシャン P26のホームペー ジ】

現在発売中の CD を郵送にて販売している。た だし，全ての注文は電子メールでのみ受け付け ており，遠隔地または路上ライブに来られない 方のみを対象としている。〔2004年11月 3 日検 索]

路上活動者自身のプロフィール, 作品紹介, 路 上活動の日時 - 場所の案内 (事例 1 ), 参加イベ ントの告知, BBS, リンク集などが, 他の路上 活動者のホームページに拈いても共通して設け られている。加えて, ダウンロードのサービス や通信販売 (事例 2 ) もよく見られた。特に

31）たとえば, 以下のような地方自治体主催の事例がある。「日本の歌声, ウチから育て 路上ライブに『演奏の場』／富 山」2001年 1 月18日, 「路上パフォーマー競演へ 柏市, 活性化へ参加者募集／千葉」2001年 7 月14日, 「ミュージシャン 育成の場作ろう 横浜音楽空間，参加者を募集 市・ NPO / 神奈川」2005年10月27日（いずれも朝日新聞より）。

32） 86 団体への聞き取り調査から, ミュージシャンでは $83.3 \%$, アーティストでは $71.4 \%$, ベンダーでは $0 \%$ ，プレイヤー では40\%の団体が自身のホームページを運営していることがわかっている。 
BBS は以下の事例に見るように多様に機能し ている。

【事例 $3 ： \mathrm{BBS}$ 上の美術系アーティスト同士の 交流】

「天王寺ミオでの『手作りぼっくすてん』やっ ています。絵本，詩集など出しています。よか ったら来て下さい」〔2004年11月 2 日検索〕

【事例 4 ：BBS 上のミュージシャン同士の交 流】

「こんにちは！！／今日梅田ですか？僕も21： 00から梅田です!どうも厳しいみたいですが, お互い頑張って搔い潜って歌いましょう！！」 〔2004年 7 月 24 日〕

「Re：こんにちは！！／今日は残念ながらすぐ に警察 3 人に止められちゃいました…遅い時 間は大丈夫でした？？」〔7月25日〕

【事例 5 : BBS 上のミュージシャンの告知】

「本日のFIGHT/いつもどおり，午後八時か らいつものアノ辺でやりますよってに!よろし $<! 」[2004$ 年11月10日18時47分〕

【事例 6 ：BBS 上の美術系アーティストと客の 交流】

「(No Subject) /今日はじめて路上で売ってる の見て，はじめて買いました。かわいらしいで す。」

$\lceil\mathrm{Re} ：($ No Subject) /日曜は暑かったのに立ち 止まってくれてありがとうございます。 HP ま で寄って頂いてホンマありがとうございまし た!!」

【事例 7 : 客と客の交流】

みい「あさってライブです」〔2004年11月21日〕 あい「みいちゃん楽しんできてね!!」〔11月 22日]

みい「あいさんこのまえはレスうれしかった です。あいさんも楽しんできてくださいね」 〔11月26日〕
以上のことから, ホームページを通じて, 路 上活動者とファンや客, 路上活動者同士, ファ ンや客同士をつなぐネットワークの一部が見え てきた。偶然路上に足を運んだ人が，路上活動 者のホームページと路上活動へのアクセスを交 互に繰り返す中で，次第にファンや固定客にな っていく。また路上に行かない人でもインター ネットの利用によって彼らの存在を知る場合も あるだろう。しかし, 路上活動者はファンや客 との結合の必要から，活動は決まった日時・場 所で繰り返されるようになる。もし変更があれ ば，BBSなどで逐一ファンに連絡することが 求められる。

さらに客との関係だけではなく，路上活動者 同士の情報交換にもホームページが役に立って いる。彼らの社会的なつながりの形態の一つと して，路上活動者間のホームページのリンクを 第 7 図にまとめた。章で触れたように，梅田 の非ミュージシャンは互いに顔見知りで親交が あるが、ミュージシャンとはあまり接点がない という状況をインターネット空間においてもう かがえる。情報化によって空間的な制約のなく なったコミュニケーションも, 何らかの価值 観・利益・文化を共有する社会的ネットワーク 内での特定の時間・場所に活動する人々の特定

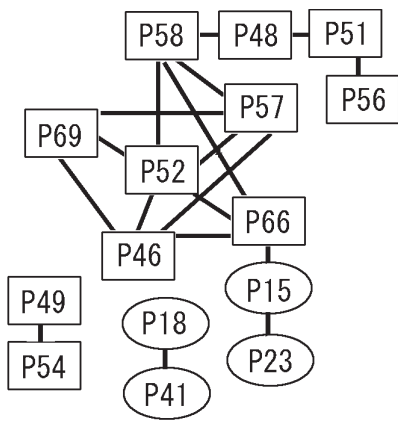

第 7 図 ホームページのリンクのつながり (2004年 9 月)

Figure 7. Cross-linked homepages of street performers.

※ミュージシャンは ○で，美術系アーティストは $\square$ で囲んでいる。 
の結びつきであり，きわめて地理的であること が，ホームページを運営する路上活動者の社会 的ネットワークに拈いて推察される。

VI むすびにかえて一時間的・空間的な活動 と社会的ネットワークの観点から一

以上，本稿では，現代都市に潜む社会と空間 との関係について, 都市の一装置である公共空 間から広がる，路上活動者の社会的ネットワー クを事例として述べてきた。

路上活動者は, 警察や活動者同士のコンフリ クトによる制約，ファンや客と接触するための
制約の中で，自分自身の生活に支障を来さない ように, 都市の時間と空間を選択していく。 個々の路上活動が同一の時刻に同一の場所で反 復される「同期化」「同所化」の実践が重なり 合って, 週末・休日の歩道橋界隈はパフォーマ ンスの舞台と化し，またミュージシャンと非ミ ユージシャンとの時間的・空間的棲み分けとし て歩道橋界隈に表出していた。

そうした梅田新歩道橋界隈で見られる路上活 動者の時間的・空間的棲み分けと，社会的ネッ トワークについてモデル的に示したのが第 8 図 である。彼らは，歩道橋空間上でバンドルを形

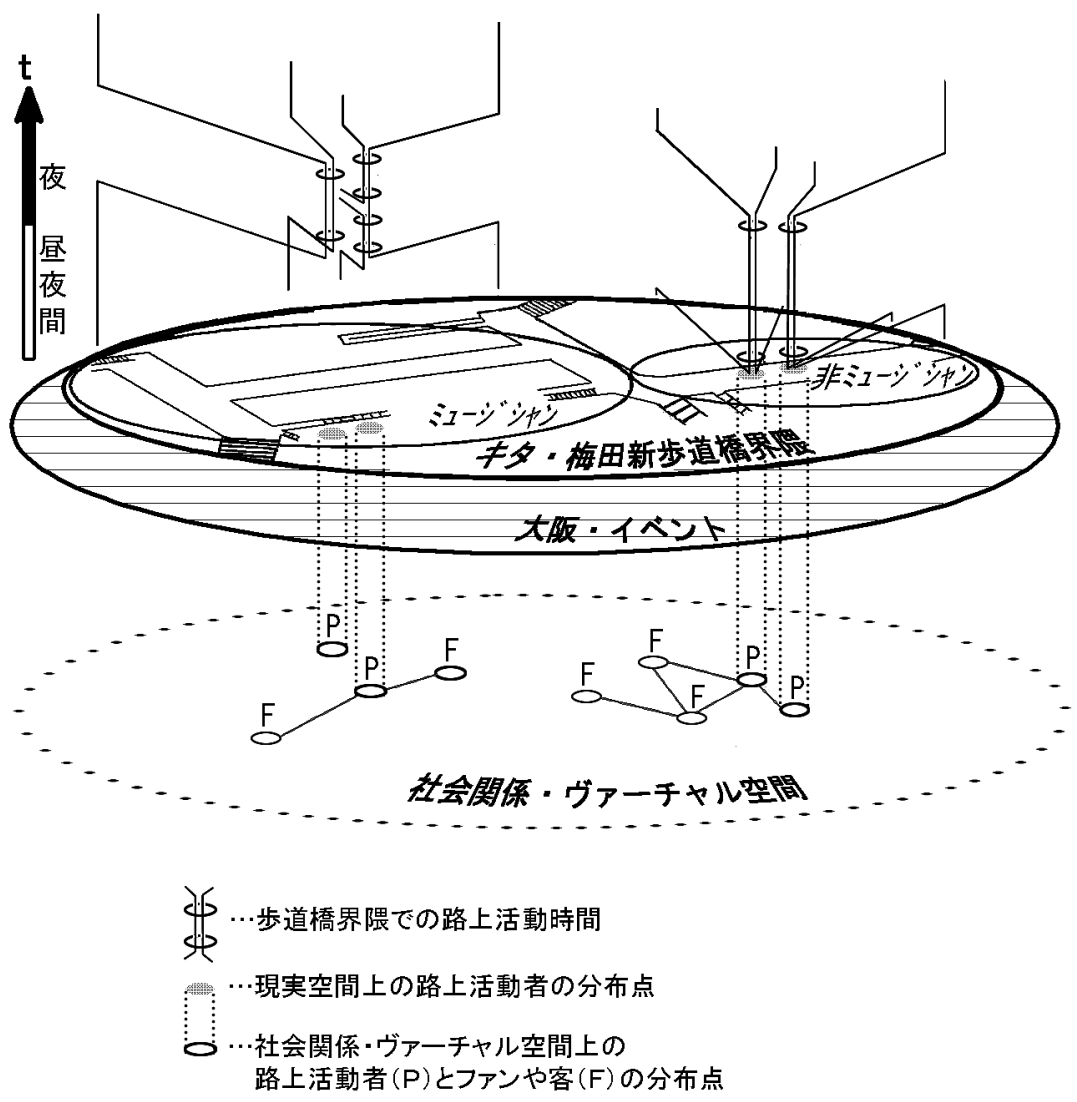

第 8 図 路上活動者の時間的・空間的棲み分けと社会的ネットワーク (モデル図)

Figure 8. Space-time segregation and social network of street performers (model figure).

33）岡本耕平「情報化と都市の生活空間」経済地理学年報46-4，2000，43-57頁。

34）神谷浩夫 ·岡本耕平・荒井良雄・川口太郎「長野県下諏訪町における既婚女性の就業に関する時間地理学的分析」地理 学評論 63A, 1990, 766-783頁。 
成しながら，ヴァーチャルな空間を含む様々な 人間関係を築いていく。この歩道橋界隈の現実 空間において, 路上活動者を, 警察, ファンや 客, あるいは他の活動者が取り巻き, 時に路上 活動を拘束し，時に路上活動しやすい環境を作 り出す。そうしたアンビバレントな環境を背景 に, 路上活動者は歩道橋界隈で時間的・空間的 パターンを繰り返し実践し，そこで社会的ネッ トワークを再生産していく。一方，時間や距離 の制約を受けない, ウェブ・サイトやテレビを 通じたヴァーチャルな空間に扮いても，社会的 ネットワークの一部が形成されている。さらに, こうした構造に大阪府内のイベントを主催する 自治体や企業が関係してくる。

梅田新歩道橋界隈では, 路上活動のバンドル 化によって構築されていく社会関係が，一種の ソーシャル・キャピタルとして活動の活性化を
助長している。そこでは, 空間と社会的ネット ワークとが多重的な関係を構築しており, 複数 の主体間の相互作用とその再生産の結節点が形 成されていると見なすことができる。

本稿では，都市の路上活動者を対象として， 時間的・空間的パターンと社会的ネットワーク の概念を関連させることによって, 時間・空 間・社会の多次元で展開する彼らの社会関係に ついて構造的に分析した。今後は，イベントの 主催者, ファンや客などの側から見た路上活動 について研究していくことを課題としたい。

[付記］本稿は2005年 3 月に大阪大学文学部に 提出した卒業論文を加筆・修正したものである。 本稿作成にあたり, キタで出会った多くの方々や, 大阪大学の小林茂先生をはじめ諸先生方, 諸先輩 方に大変扔世話になりました。この場を借りて厚 く御礼申し上げます。 


\title{
The Activities of Street Performers and Their Social Networks in Kita, Osaka
}

\author{
Miki Kazumi
}

This study considers the activities of street performers on and around the new Umeda footbridge in Kita, Osaka. In this study, the perspectives of time geography and social networks are emphasized.

The following conclusions can be drawn as a result of field observations and personal interviews with street performers,

The various street performers are divided into 4 types: (1) musicians, (2) fine artists, (3) vendors, and (4) other performers. Based on these types, the purpose of their street activity varies and their space-time distribution patterns can be seen around the new Umeda footbridge.

The environment surrounding the street performers consists of the police and municipalities, local companies, media organizations, fans and visitors. On the one hand, they regulate the activities of the street performers, while, on the other, they are affected by the independent activities of the street performers.

Against the background of the spread of the Internet, street performers form social networks by creating their own homepages.

From knowledge of time geography and social networks, this paper analyzed various structural relations around street performers. Street activities in the city are understood as an example exhibited in many dimensions of time, space and society.

Keywords : street performers, Kita, social network, time geography, society and space 